\section{UDC 008 (477):7.04}

https://doi.org/10.32689/2617-22242020-4(24)-163-172

\section{Коннова Майя Вікторівна,}

кандидат історичних наук, доцент кафедри управління та адміністрування КВНЗ "Вінницька академія неперервної освіти", 21100, м. Віннии,я, вул. Грушевського, 13, тел.: +38 (097) 40906 89, e-mail: mkonnova@gmail.com, https:// orcid.org/0000-0002-7579-682x

\section{Коннова Майя Викторовна,}

кандидат исторических наук, доцент кафедры управления и администрирования КВУЗ "Винницкая академия непрерывного образования", 21100, г. Винница, ул. Грушевского, 13, тел.: +38 (097) 40906 89, e-mail: mkonnova@gmail.com, https:// orcid.org/0000-0002-7579-682x

\section{Konnova Maya Viktorivna,}

Candidate of Historical Sciences, Associate Professor of Management and $A d$ ministration Community Higher Education Institution "Vinnitsa Academy of Continuing Education", 21100, Vinnytsia, street Hrusherskoho, 13, tel.: +38 (097) 40906 89, e-mail: mkonnova@gmail.com, https://orcid.org/0000-0002-7579-682x

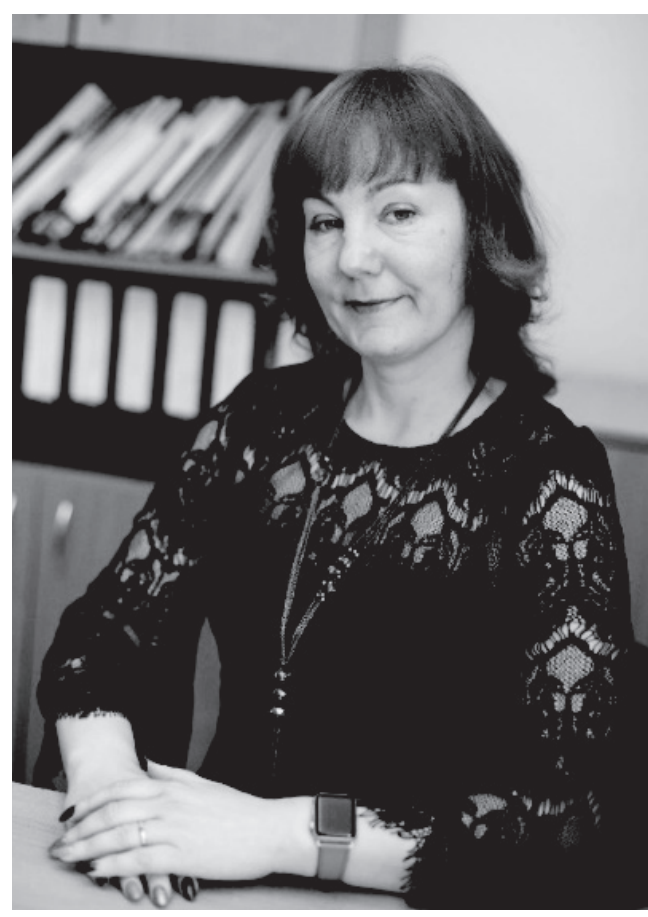

\title{
ФОРМИ ТА ПРИНЦИПИ ОРГАНІЗАЦІЇ ПУБЛІЧНОЇ ВЛАДИ ЧАСІВ КОЗАЦЬКОЇ ДЕРЖАВИ
}

Анотація. Схарактеризовано механізми формування принципів та форм функціонування державної влади козацько-гетьманської України; встановлено особливості формування інституційних засад українського державотворення як складного та суперечливого процесу козацької доби; обгрунтовано, що упродовж усього періоду існування запорозької спільноти є природна система державного управління, яка сформувала форми підгрунтя політичного устрою та мотивувала його життєзабезпечення і сформувала основні принципи козацтва як тогочасної політичної еліти. Ї̈̈ принципами були: подільність (Січ поділялася на курені, максимально їх було 38), територіальність - на паланки (п'ять-вісім), виборність (козаки куреня підлягали владі виборного курінного отамана). Дослідження та аналіз наукових й історичних джерел засвідчило, що більшість науковців вважають, що в часи козацької держави можна дослідити вже структуру публічної влади, елемен- 
ти якої ідентичні, якою мірою, до сучасних форм публічної влади; формою вищого органу самоуправління, яка розв’язувала найважливіші питання, була військова рада, яка грунтувалася на засадах щирого братерства, взаємодопомоги. Адже вся система органів державотворення забезпечувалась шляхом формування військово-адміністративної влади через виконання принципів внутрішніх і зовнішніх функцій, властивих державі. Основною формою публічної влади була загальна рада, окрім іншого, вона формувала різного рівня виконавчу, судову та військову владу Війська Запорозького, зокрема, обирали гетьмана, влада якого поширювалася на усіх козаків Війська Запорозького, в тому числі на тих, які мешкали на волості, тобто на заселених територіях України, насамперед у межах Київського та Брацлавського воєводств.

Встановлено, що форми та принципи організації козацького самоврядування Запорозької Січі забезпечували виконання функцій, властивих державі. Це дає підстави стверджувати, що тут відроджувалася українська державність.

Ключові слова: демократичне врядування, державотворення, військова рада, військова старшина, звичаєве право, принципи, самоврядування, січове товариство, форми.

\section{ФОРМЫ И ПРИНЦИПЫ ОРГАНИЗАЦИИ ПУБЛИЧНОЙ ВЛАСТИ ВРЕМЕН КАЗАЦКОГО ГОСУДАРСТВА}

Аннотация. Охарактеризованы механизмы формирования принципов и форм функционирования государственной власти казацко-гетманской Украины; установлены особенности формирования институциональных основ украинского государства как сложного и противоречивого процесса казачества; обосновано, что течение всего периода существования Запорожской Сечи является естественной системой государственного управления, которая сформировала основные принципы казачества как тогдашней политической элиты. Ее принципами были делимость (Сечь делилась на курени, максимально их было 38), территориальность - на паланки (пять-восемь), избирательность (казаки куреня принадлежали власти выборного куренного атамана). Исследования и анализ научных и исторических источников показало, что большинство ученых считают, что во времена казацкого государства можно исследовать уже структуру публичной власти, элементы которой идентичны, в какой-то мере, до современных форм публичной власти как формы высшего органа самоуправления. Важнейшие вопросы решал военный совет, который основывался на принципах истинного братства, взаимопомощи. Вся система органов государства обеспечивалась путем формирования военно-административной власти через выполнение принципов внутренних и внешних функций, присущих государству. Основной формой публичной власти был также общий совет, помимо прочего, он формировал разного уровня исполнительную, судебную и военную власть Войска Запорожского, в частности, выбирали гет- 
мана, власть которого распространялась на всех казаков Войска Запорожского, в том числе на тех, которые жили в волости, то есть на заселенных территориях Украины, прежде всего в пределах Киевского и Брацлавского воеводств.

Установлено, что формы и принципы организации казацкого самоуправления Запорожской Сечи обеспечивали выполнение функций, присущих государству. Это дает основание утверждать, что именно там возрождалась украинская государственность.

Ключевые слова: демократическое управление, государство, военный совет, военачальники, право, принципы, самоуправление, сечевое общество, формы.

\section{FORMS AND PRINCIPLES OF ORGANIZATION OF PUBLIC AUTHORITY OF THE TIME OF THE COSSACK STATE}

Abstract. The article describes the mechanisms of formation of the principles and forms of functioning of the state power of the Cossack-Hetman Ukraine; the peculiarities of the formation of the institutional foundations of the Ukrainian state as a complex and contradictory process of the Cossacks are established; it is substantiated that during the whole period of existence of the Zaporozhian Sich there is a natural system of public administration, which formed the basic principles of the Cossacks as the then political elite. The principles of which were divisibility (Sich was divided into huts, there were a maximum of 38), territoriality - into palanquins (five or eight), selectivity (Cossacks of the hut belonged to the authorities of the elected smokehouse ataman). Research and analysis of scientific and historical sources have shown that most researchers believe that in the days of the Cossack state it is possible to study the structure of public power, the elements of which are identical, to some extent, to modern forms of public power as the highest self-government. The most important issues were decided by the military council, which was based on the principles of true brotherhood and mutual assistance. The entire system of state bodies was ensured through the formation of military-administrative power through the implementation of the principles of internal and external functions inherent in the state. The main form of public power was also the general council, among other things, it formed different levels of executive, judicial and military power of the Zaporozhian Army, in particular, elected a hetman, whose power extended to all Cossacks of the Zaporozhian Army, including those who lived in the parish, that is, in the populated areas of Ukraine, primarily within the Kiev and Bratslav provinces.

We came to the conclusion that the forms and principles of organization of the Cossack self-government of the Zaporozhian Sich ensured the performance of the functions inherent in the state. This gives grounds to claim that it was there that Ukrainian statehood was revived.

Keywords: democratic governance, state, military council, military leaders, law, principles, self-government, forms. 
Постановка проблеми. Українське козацтво було силою, яка прагнула реалізувати політичні та державницькі ідеали українського етносу, здійснило вирішальний вплив на становлення в українському суспільстві нових моделей світосприйняття й нової політичної культури, сформувало українську ідентичність та ментальність. Українська держава Козацької доби була формою найвищого розвитку українського етносу в ранньомодерній історії України, свідченням його державотворчого потенціалу, суттєвою передумовою до реалізації в українському суспільстві процесів націєтворення, ідеалами якого були співзвучними демократичним принципам рівноправ'я, соціальної справедливості, визнання цінності особистості та їі свободи.

Аналіз останніх досліджень та публікацій. Серед вітчизняного наукового доробку слід пригадати такі імена дослідників як О. Апанович, О. Гуржій, Ю. Мицик, Г. Сергієнко, В. Сергійчук, В. Смолій, В. Степанков, I. Стороженко, Н. Яковенко, В. Горобець, В. Голубоцький.

Мета статті - проаналізувати особливості форм і принципів публічної влади часів козацької держави та їх вплив на державно-правове становище України.

\section{Виклад основного матеріалу} дослідження. Вивчення та аналіз історичних джерел показало, що дослідники виявили багато свідчень учасників про невгамовну жагу селян і міщан досягти козацького статусу. Упродовж усього періоду існування запорозької спільноти демократичне врядування як природ- на система державного управління сформувало форми підгрунтя політичного устрою та мотивувало його життєзабезпечення. Як історичний чинник, вони відігравали першочергову роль у формуванні основних принципів козацтва як тогочасної політичної еліти [1, с. 78-88].

У результаті цього фундатор української державності періоду Нового часу гетьман Б. Хмельницький залишив традиційну назву для української козацької держави - Військо Запорозьке, віддаючи данину традиціям і формам демократичного врядування Запорозької Січі [2, с. 22], принципами якої були подільність (Січ поділялась на курені, максимально їх було 38), територіальність - на паланки (п'ять-вісім), виборність (козаки куреня підлягали владі виборного курінного отамана).

Формою вищого органу самоуправління була військова рада за участю всіх козаків, що розв'язувала найважливіші питання. Ради скликалися за потреби, але обов'язково на Різдво й Покрову. Скликалися також ради в куренях і паланках.

Дослідження i аналіз наукових джерел засвідчило, що в часи козацької держави можна було дослідити вже структуру публічної влади, елементи якої ідентичні, якою мірою, до сучасних форм публічної влади. Відмовляючись визнавати авторитет будь-якого правителя, запорожці здійснювали самоврядування згідно 3 тими звичаями і традиціями, які формувалися впродовж поколінь. Усі запорожці мали рівні права, їх відносини грунтувалися на засадах щирого братерства, взаємодопомоги. Устрій запорозької спільноти базувався на 
республікансько-демократичних засадах [3]. Уся військова старшина обиралася Військовою радою на рік. Найвищу владу після Військової ради мав кошовий отаман - військову, адміністративну, судову. Він був підзвітний Військовій раді. Другою особою після отамана вважався військовий суддя, який виступав гарантом споконвічних звичаїв січової спільноти. У своїх рішеннях він керувався звичаєвим правом, що передавалося 3 вуст в уста. Зовнішньою ознакою влади була велика срібна печатка, якою скріплювалися усі постанови січового товариства. Окрім суддівських функцій він заступав кошового отамана, був начальником артилерії. Курені були адміністративними й військовими одиницями. Очолювали їх виборні та підзвітні раді курінні отамани [3].

Військовий осавул наглядав за дотриманням козаками порядку й дисципліни, стежив за виконанням судових рішень ради та отамана, проводив дізнання за вчинені правопорушення тощо [4, с. 56].

Організація козацького самоврядування Запорозької Січі дає підстави стверджувати, що тут відроджувалася українська державність. Адже вся система органів військово-адміністративної влади забезпечувала виконання внутрішніх і зовнішніх функцій, властивих державі. На загальних козацьких радах, окрім іншого, формували різного рівня виконавчу, судову та військову владу Війська Запорозького. Приміром, обирали гетьмана, влада якого поширювалася на усіх козаків Війська Запорозького, в тому числі на тих, які мешкали на волості, тобто на за- селених територіях України, насамперед у межах Київського та Брацлавського воєводств.

На радних зібраннях обирали військових командирів і начальників, наприклад полковників (очільників військових підрозділів, що налічували до кількох тисяч козаків), приймали рішення про участь у війні, затверджували плани конкретних бойових операцій, зачитували дипломатичну кореспонденцію, яка надходила від різних адресантів, приймали іноземних послів, формували склад козацьких посольств до польського короля та іноземних володарів, визначали й затверджували їм посольські інструкції, іноді ухвалювали й виконували судові вироки тощо. На козацьких радах обирали також владний провід Запорозької Січі, в тому числі, кошового отамана, який, з одного боку, мав владу над січовими козаками, а з іншого - підпорядковувався запорозькому гетьманові.

Діяльність загальних козацьких рад базувалася на прямій демократії козацького кола. Це означало, що кожен повноправний козак мав можливість безпосередньо впливати на формування внутрішньої та зовнішньої політики Війська Запорозького. В умовах козацького способу життя, пов'язаного 3 постійною потребою мобілізувати соціум Війська Запорозького на вирішення нагальних військових завдань, а також адекватного реагування на виклики корпоративним інтересам запорозької спільноти в політичній, соціальній та економічній сферах, загальна рада була інструментом станового народовладдя [4, с. 28]. 
Пряма демократія загальної козацької ради мала й слабкі сторони. Приміром, багатотисячна юрба аж ніяк не могла фахово вести переговори або напрацьовувати текст документів. Щоправда, для цього було знайдено прийнятний механізм попередньої підготовки питань порядку денного: на загальній козацькій раді формували групу компетентних й авторитетних запорожців, насамперед iз числа старшини, які виконували відповідну підготовчу роботу та представляли іiі результати на розгляд загальної ради. Однак не всі проблеми прямої демократії козацького кола можна було легко вирішити. Йдеться, зокрема, про те, що великі маси запорожців, які збиралися на раді, не були застраховані від психології натовпу. Тож вони не завжди дослухалися до раціональних аргументів і легко піддавалися навіюванню та охлократичним настроям. "Голос народу", незалежно від того, був виважений чи імпульсивний та емоційний, не надто подобався тим старшинам, які дбали насамперед про свої інтереси, бо побоювалися втратити на раді владу або й життя. До складнощів козацької демократії можемо віднести й те, що козаки не завжди могли оперативно й без проблем зібратися на раду, рішення якої без зайвих зволікань поставали за результатами прямого волевиявлення [4, с. 57].

У процесі формування української держави загальна військова рада 3 військової установи трансформувалася в орган державної влади. Але до цього часу дослідники сучасних форм та принципів становлення публічної влади відмічають ці самі слабкі їі сторони.
Систему вищих виконавчих органів влади періоду Національної революції другої половини XVII ст. уособлював Генеральний уряд. Він уважався головним розпорядчим, виконавчим і судовим органом козацько-гетьманської держави. До складу Генерального уряду входили гетьман, генеральні старшини й центральні органи виконавчої та судової влади генеральні військові канцелярії.

Інститут гетьманства посідав надзвичайно важливе місце в політичній системі козацько-гетьманської держави. Зміна влади гетьмана неодмінно екстраполювалася на державно-правове становище України. Виборний гетьман зосереджував у своїх руках надзвичайно широке коло владних повноважень у сфері законодавчої, виконавчої та судової влади. Він скликав Генеральну раду і Старшинську раду, керував ними, брав участь в обговоренні питань і ухваленні рішень рад, організовував їх виконання, очолюючи адміністрацію; за гетьманським підписом виходили найважливіші розпорядження та універсали - правові акти, що мали силу закону; він також очолював судочинство, виступаючи вищою апеляційною інстанцією; організовував і керував фінансами, встановлював податки, розпоряджався земельним фондом; визначав напрями зовнішньополітичної діяльності країни; очолював військо [4, с. 78].

Юридичну основу влади гетьмана складали норми усного звичаєвого права - “давні права та вольності”, пристосовані до державного статусу України, міждержавні договори й санкціоновані державою законодавчі акти. Конституційним актом ді- 
яльності гетьмана стали “Статті про устрій Війська Запорозького”, прийняті загальною військовою радою у червні 1648 р. Козацький звичай передбачав також посаду наказного гетьмана - тимчасового виконувача обов'язків гетьмана. Правління наказного гетьмана встановлювалося за умов, коли посада гетьмана ставала вакантною, коли гетьман не міг виконувати своїх обов'язків за станом здоров'я, коли гетьман тимчасово залишав столицю, а також із метою проведення воєнної операції чи для виконання інших завдань [4, c. 23]. Окремі автори стверджують, що наказне гетьманство було інститутом, який забезпечував функціонування в період Руїни і став перепоною на шляху скочування України до анархії.

Генеральна старшина - обозний, писар, два судді, два осавули, хорунжий та бунчужний - відігравала важливу роль у системі організації політичної влади козацько-гетьманської держави. Генеральні старшини були обов'язковими учасниками Старшинських рад, виступали в ролі виконавців постанов гетьмана i Старшинської ради, а також - найближчих порадників гетьмана, утворюючи при ньому дорадчий орган раду генеральної старшини, на яку покладалося завдання оперативного управління країною. Функції колегії генеральних старшин, як своєрідного дорадчого органу при гетьмані, закріплювалися традиціями української держави, а також фіксувалися в українсько-російських угодах другої половини XVII ст.

Значення генеральної старшини значно зростало в часи міжгетьман- ства, яка реалізовувала свої повноваження через раду генеральної старшини. Існує думка, що в механізмі генерального уряду рада генеральної старшини виконувала єднальні функції між гетьманом і радою старшин. Генеральну старшину призначав гетьман чи обирала рада старшин на невизначений термін. Гетьман i рада старшин також звільняли генеральних старшин із займаних посад. Отже, в українській державі часу Національної революції другої половини XVII ст. демократичний спосіб формування посад генеральних старшин у спосіб виборів загальною військовою радою не розвинувся [4, c. 139-141].

Місцеві органи влади та управління гетьманської держави - полковий i сотенний уряди, міське й сільське управління - наслідували організації центральної влади, що грунтувались, насамперед, на потребах оперативної мобілізації збройного люду. Адміністративний поділ козацько-гетьманської держави, що поділявся на полки й сотні, дублював структуру війська: територіальні одиниці відповідали ієрархї бойових підрозділів, забезпечуючи максимально швидку мобілізацію козацького стану [4, с. 13-14].

До складу полкового уряду входили полкова козацька рада, полковник, полкові старшини, рада полкової старшини і полкові канцелярії. На підставі звичаю полковий уряд підпорядковувався полковій козацькій раді. Полкова козацька рада мала однотипний iз загальною військовою радою механізм формування та принципи функціонування, їй належало право формувати полковий уряд, 
затверджувати або скасовувати його рішення. Оскільки полкова козацька рада обмежувала владні повноваження гетьмана, полковників і полкової старшини, вони не були зацікавлені в ㄲï розвитку. Тому генеральний i полковий уряди поступово на кінець XVII ст. перетворили полкову козацьку раду на формальність [5, с. 38].

Полковий уряд очолювали полковники, які виступали як представники військової адміністративної влади на території полку та були виконавцями доручень гетьмана, Генеральних і Старшинських рад [4, c. 218-220].

Полковникам у межах полку належали широкі військові, адміністративні, фінансові та судові повноваження. Вони забезпечували мобілізацію ввіреного їм військового підрозділу, дбали про його боєздатність, забезпечували його дисципліну, доглядали за станом фортифікаційних споруд тощо. Полковники здійснювали всю повноту розпорядчих функцій на підвладній їм території. Насамперед вони розпоряджалися земельним фондом (“ранговими маєтностями”), який склали землі, залишені шляхтою. Полковники розподіляли ці землі між старшиною і козаками, як плату за несення ними військової служби. Вони також організовували фінансову справу, керували збором податків до військового скарбу, віддавали в оренду промисли, що належали до військового фонду, збирали орендну плату. Повноваження полковників у поземельних i фінансових справах ставили під їх контроль також міське господарство й давали змогу втручатись у внутрішні справи міст.
Особу, яка тимчасово виконувала обов'язки полковника, називали наказним полковником [5, с. 48]. В управлінні територією полку та командуванні військовим підрозділом полковник спирався на полкову старшину, склад якої майже повністю дублював склад генеральної старшини - обозний, суддя, осавул, писар, хорунжий. Матеріальним забезпеченням полку відав обозний. Він керував обозом та артилерією, за відсутності полковника виконував його обов’язки. Обозному підлягали полковий артилерійський осавул, полковий артилерійський писар, хорунжий полкової артилерії та отамани. У полковому суді головував полковий суддя. Він мав свою канцелярію та урядовців. Писар вів діловодство полку й керував полковою канцелярією. Осавул (найчастіше їх було два) наглядав за дотриманням порядку й дисципліни у полку, виконував поліційні функції. Мав помічника - підосавула. Полковий хорунжий відповідав за збереження полкового прапора та виконував тимчасові доручення гетьмана чи Ради.

Управлінською і технічною установою полкового уряду була полкова канцелярія. У межах полку вона виконувала загалом такі самі функції, що й генеральна військова канцелярія на загальнодержавному рівні. Полкова канцелярія розвинулась у провідну установу полкового уряду. Вона забезпечувала механізм взаємодії генерального, полкового й сотенного урядів.

Вважається, що полковий уряд складав основу організації державної влади козацько-гетьманської 
України. На нього спирався у своїй діяльності генеральний уряд. Тому генеральний уряд всебічно сприяв удосконаленню й розвитку полкових урядів [5, с. 216-218].

Модель адміністративного устрою полку копіювалася на сотенному рівні. До складу сотенного уряду входили сотник, городові отамани, сотенні старшини, сотенна рада старшин і сотенна канцелярія.

Право формувати сотенний уряд, затверджувати чи скасовувати його постанови належало сотенній козацькій раді, якій, відповідно до звичаю, він підпорядковувався. За механізмом формування та за принципами функціонування сотенна козацька рада була установою, однотипною з полковою козацькою радою. Однак до кінця XVII ст. окремі повноваження сотенної козацької ради привласнили гетьман, полковник і сотник.

Під керівництвом сотника сотенний уряд ухвалював рішення про надання чи відторгнення земельних угідь, про збір податків, розпоряджався скарбом сотні, проводив перепис населення і майна, провадив нотаріальні дії, встановлював повинності [6, с. 31]. Однак до кінця XVII ст. окремі повноваження сотенної козацької ради привласнили гетьман, полковник і сотник. Під керівництвом сотника сотенний уряд ухвалював рішення про надання чи відторгнення земельних угідь, про збір податків, розпоряджався скарбом сотні, проводив перепис населення й майна, провадив нотаріальні дії, встановлював повинності [6, с. 31]. У процесі формування української держави загальна вій- ськова рада $з$ військової установи трансформувалася в орган державної влади.

Висновки. На підставі дослідження було встановлено, що в історичному процесі формування української держави можна розглядати як підгрунття трансформації загальної військової ради із військової установи в орган державної влади.

Дослідження засвідчило, що вищою формою органу самоуправління була Рада (військова) з відповідним регламентом скликання та авторитетом правителя. Гілки влади представлялися військовою, адміністративною, судовою формами самоуправління. Суд виступав гарантом звичаїв січової спільноти.

Дослідники сучасних форм та принципів становлення публічної влади відмічають саме ці слабкі іiі сторони. Будувалась модель місцевого самоврядування (на прикладі адміністративного устрою полку). За механізмом формування та за принципами функціонування сучасна місцева рада до цього часу є варіантом полкової козацької ради (сотенна козацька рада була установою, однотипною з полковою козацькою радою, яка мала б забезпечувати механізми взаємодії генерального, полкового й сотенного урядів).

Підтвердженням цього є принципи створення сучасної Верховної Ради України, яка до цього часу не спромоглася ефективно об'єднати механізми взаємодії всіх гилок влади в умовах децентралізації, чим і порушує своє основне призначення в публічній владі України, це може бути питанням подальшого дослідження. 
СПИСОК ВИКОРИСТАНИХ ДЖЕРЕЛ

1. Леп’явко C. А. Великі кордони українців // Гілея: наук. вісн. 2011. Вип. 42. C. 78-88.

2. Апанович O. М. Гетьмани України та кошові отамани Запорізької Січі. Київ: Либідь, 1993. 287 с.

3. Коннова M. B. Історічні аспекти формування системи управління та адміністрування на українських землях козацької доби. Вінниця: КВН3 “ВАНО”, 2020. С. 198-208.

4. Смолій В. Козацтво та Запорізька Січ у суспільно-політичних процеcax XVI-XIX ст. // Козацькі Січі (Нариси з історії українського козацтва XVI-XIX ст.). Київ; Запоріжжя, 1998. $251 \mathrm{c}$.

5. Панашенко В. Соціальна еліта Гетьманщини (друга половина XVIIXVIII). Київ, 1995. 221 с.

6. Олійник О. Л. Врядування в Україні княжої та козацької доби. Запоріжжя : Класич. приват. ун-т, 2012. $320 \mathrm{c}$.

\section{REFERENCES}

1. Lepiazko, S.A. (2011). Velyki kordony ukraintsiv [Great Ukrainians' borders]. Hileia - Gileya, 42, 78-88 [in Ukrainian].
2. Apanozych, O. M. (1993). Hetmany Ukrainy ta koshovi otamany Zaporizkoi Sichi [Hetmans of Ukraine and Kish atamans of the Zaporozhian Sich]. Kyiv: Lybid [in Ukrainian].

3. Konnova, M. V. (2020). Istorichni aspekty formuvannia systemy upravlinnia ta administruvannia ukrainskykh zemliakh kozatskoi doby [Historical aspects of the formation of the system of management and administration of the Ukrainian lands of the Cossack era]. Vinnytsia: KVNZ "VANO" [in Ukrainian].

4. Smolii, V. (1998). Kozatstvo ta Zaporizka Sich u suspilno-politychnykh protsesakh XVI-XIX st. [Cossacks and Zaporozhian Sich in the sociopolitical processes of the XVI-XIX centuries]. Kozatski Sichi (Narysy z istorii ukrainskoho kozatstva XVIXIX st.) - Cossack Sich (Essays on the history of the Ukrainian Cossacks of the XVI-XIX centuries. (pp. 3-14). Kyiv; Zaporizhzhia [in Ukrainian].

5. Panashenko, V. (1995). Sotsialna elita Hetmanshchyny (druha polovyna XVII-XVIII) [Social elite of the Hetmanate (second half of XVIIXVIII)]. Kyiv [in Ukrainian].

6. Oliinyk, O. L. (2012). Vriaduvannia v Ukraini kniazhoi ta kozatskoi doby [Governance in Ukraine of the princely and Cossack era]. Zaporizhzhia: Klasychnyi pryvatnyi universytet [in Ukrainian]. 